\title{
AROMATIC AND FATTY ACIDS OF TRITERPENE ESTERS AND RUBBER CONTENT OF HOYA LATICES AND THEIR TAXONOMIC SIGNIFICANCE*
}

\author{
FRANS WARNAAR \\ Botanical Laboratory, State University of Utrecht, Lange Nieuwstraat 106, 3512 PN Utrecht, The Netherlands
}

(Received 16 September 1983)

Key Word Index-Hoya; Asclepiadaceae; triterpene esters; aromatic acids; rubber; latex; chemotaxonomy.

\begin{abstract}
The acid composition and the rubber content of the latices of 20 Hoya species were determined. All acids isolated from the latices were esterified with triterpenols and particle-bound. Cinnamic acid was the main acid in most latices. Acetic acid occurred in all latices, and predominated in three of the investigated species. Isovaleric acid and benzoic acid were present in some species; in one latex $(H$. bella) isovaleric acid was the predominant acid. Almost all species contained small amounts of phenylpropionic acid, and in two species this acid was a major compound. Longchain fatty acids were present as minor compounds. Rubber occurred in all particle-containing latices; its contribution to the total lipid fraction ranged from $1.7-24.0 \%$. The acid profiles proved to be species-specific in Hoya and may be useful in species identification. Patterns of latex particle synthesis are proposed.
\end{abstract}

\section{INTRODUCTION}

Most plant latices contain particles consisting of rubber, triterpenoids, alkanes and small amounts of phospholipids and proteins [1]. The triterpenoids of latices usually consist of triterpenols and their esters. The esterifying acids are mainly acetic and long-chain fatty acids. Aromatic acids and uncommon fatty acids, however, are also found in the latex particles of several plant species of different families. Cinnamic acid, for instance, was isolated from the latices of Asclepiadaceae [2-4], Moraceae [5-7], and Sapotaceae [8-13]. Some Asclepiadaceae contain $\alpha$-hydroxy fatty acids [14] or isovaleric acid [15-17] as prominent acids esterified with triterpenols. More recently it has been shown that conjugated fatty acids also can be present as triterpene esters in latex particles of Euphorbia species [18, 19].

The lipid fraction of the latices of Hoya species (Asclepiadaceae) consists mainly of triterpenols and their esters [3, 4, 20-22]. Baas et al. [23] showed that the triterpene profiles of the latices of Hoya are constant and species-specific. The acid moieties of triterpene esters in Hoya latices are mainly acetate, isovalerate and cinnamate $[3,17,23]$.

The main purpose of the present study was to investigate the composition of the esterified acids of Hoya latices and to evaluate the taxonomic potential of latex chemistry.

\section{RESULTS AND DISCUSSION}

\section{Lipid composition of latex particles}

Two of the investigated species (H. carnosa and $H$. motoskei) contain a clear 'latex' in which particles are

*Part 7 in the series "Investigations on Hoya species". For part 6 see: Baas, W. J., Warnaar, F. and Niemann, G. J. (1981) Acta Bot. Neerl. 30, 257. absent; in these latices lipids were not detectable. The lipid extracts of the particle-containing latices of all other Hoya species contained mainly neutral lipids and consisted of cis-polyisoprene (rubber), triterpenols and triterpene esters (Table 1).

The contribution of rubber to the neutral lipid fractions ranged from ca $2-24 \%$ by wt. However, the range of rubber content found in the latex particles of Apocynaceae [24] and Moraceae [25] was more extensive. An unequal distribution of rubber has been found in these families: most of the genera showed a rubber content of $2-19 \%$, but another group had a rubber content of $80-96 \%$. For Hoya, all species fall into the first group and none in the latter. A further subdivision within the first group, such was made for the latices of Apocynaceae genera [24], could not be made within the genus Hoya.

Table 2 shows the free triterpenol and triterpene ester composition of the latex particles of 20 Hoya species. Free triterpenols were present in all of them ranging from $4-23 \%$ of the total triterpenoid fraction. In Apocynaceae latices $15-30 \%$ of the triterpenoids were found as free triterpenols [24]. The remaining part of the triterpenoids consisted of triterpenols esterified with different acids.

\section{Aliphatic and aromatic acids of the triterpene esters}

Triterpene acetates occur in all the Hoya species investigated (Table 2 ) and range from 4-84\% of the total triterpenoid fraction. Cinnamic acid turned out to be a main acid in most latices; it was mainly present as the trans isomer, After saponification-methylation of the triterpene ester fraction, however, cis-cinnamic acid could be detected as well. The contribution of the latter ranged from $0.1-1 \%$ of total cinnamic acid, with the exception of $H$. bella, the latex of which contained about $2 \%$ of the cinnamic acid in the cis configuration. Triterpene ciscinnamates are formed from trans-cinnamates during prolonged exposure to light [21]. This effect, however, was avoided by the use of freshly tapped latices, in which 
Table 1. Particle composition of the latex of Hoya species

\begin{tabular}{|c|c|c|c|c|c|}
\hline \multirow[b]{2}{*}{ Species } & \multirow[b]{2}{*}{ No* } & \multicolumn{4}{|c|}{$\%$ of particles } \\
\hline & & $\begin{array}{l}\text { mg particles/g } \\
\text { fresh latex }\end{array}$ & Rubber & $\begin{array}{c}\text { Free } \\
\text { triterpenol }\end{array}$ & $\begin{array}{l}\text { Triterpene } \\
\text { ester }\end{array}$ \\
\hline H. carnosa R.Br. & 35 & - & - & - & - \\
\hline H. motoskei Teysm. & 155 & - & - & - & - \\
\hline$H$. species & $X-20$ & 59 & 6.8 & 3.3 & 89.9 \\
\hline H. australis R.Br. ex Traill. & 18 & 72 & 6.0 & 10.7 & 83.3 \\
\hline H. latifolia G.Don. & 128 & 72 & 4.0 & 18.6 & 77.4 \\
\hline H. crassipes Turcz. & 53 & 73 & 21.8 & 6.3 & 71.9 \\
\hline H. diversifolia Blume & 62 & 83 & 21.8 & 8.9 & 69.3 \\
\hline H. fraterna Blume & 84 & 84 & 19.6 & 6.8 & 73.6 \\
\hline H. bandaensis Schlechter & 20 & 103 & 12.9 & 15.9 & 71.2 \\
\hline H. ovalifolia Wight et Arn. & 180 & 106 & 8.5 & 9.1 & 82.4 \\
\hline H. cinnamomifolia Hook. & 43 & 107 & 23.6 & 4.8 & 71.6 \\
\hline H. coronaria Blume & 50 & 109 & 13.8 & 4.7 & 81.5 \\
\hline$H$. species & $X-4$ & 115 & 13.9 & 13.7 & 72.4 \\
\hline H. lacunosa Blume & 122 & 122 & 12.3 & 11.1 & 76.6 \\
\hline H. macrophylla Blume & 146 & 138 & 2.6 & 14.7 & 82.7 \\
\hline H. obovata Decne & 168 & 145 & 20.1 & 6.9 & 73.0 \\
\hline H. shepherdii Short & $X-5$ & 156 & 14.3 & 14.2 & 71.5 \\
\hline H. bella Hook. & 21 & 172 & 8.7 & 11.1 & 80.2 \\
\hline H. angustifolia Elmer & 9 & 176 & 5.7 & 22.1 & 72.2 \\
\hline H. pseudolanceolata Cost. & 207 & 192 & 2.8 & 7.2 & 90.0 \\
\hline H. multiflora Blume & 156 & 219 & 1.7 & 6.4 & 91.9 \\
\hline H. imperialis Lindl. & 110 & 308 & 3.4 & 20.0 & 76.6 \\
\hline
\end{tabular}

* The numbers refer to the collection numbers of the plants cultivated in the greenhouse.

Table 2. Triterpenol and triterpene ester composition of the latex particles of Hoya species in mol \%

\begin{tabular}{lcccccc}
\hline Species & $\begin{array}{c}\text { Free } \\
\text { triterpenols }\end{array}$ & T. acetates & T. isovalerates & T. aromates & T. lcfa * & $\begin{array}{c}\text { mol triterpenoid/g } \\
\text { particles }\end{array}$ \\
\hline H. spec. X-20 & 4.2 & 6.3 & - & 78.3 & 11.2 & 1.98 \\
H. coronaria & 5.5 & 22.4 & - & 70.0 & 2.1 & 2.00 \\
H. cinnamomifolia & 6.3 & 8.2 & - & 82.9 & 2.6 & 1.28 \\
H. multiflora & 6.5 & 80.8 & 8.4 & 1.0 & 3.3 & 1.67 \\
H. pseudolanceolata & 7.4 & 12.0 & - & 78.6 & 1.9 & 1.83 \\
H. crassipes & 8.0 & 3.8 & - & 86.1 & 2.1 & 1.71 \\
H. fraterna & 8.5 & 1.1 & - & 89.0 & 1.3 & 1.74 \\
H. obovata & 8.6 & 11.8 & - & 78.5 & 1.1 & 1.51 \\
H. ovalifolia & 9.9 & 17.2 & - & 70.9 & 2.0 & 1.73 \\
H. diversifolia & 11.3 & 5.5 & - & 81.8 & 1.4 & 1.43 \\
H. australis & 11.4 & 12.3 & 0.2 & 73.6 & 2.4 & 1.47 \\
H. bella & 12.2 & 11.1 & 65.9 & 5.5 & 5.3 & 1.72 \\
H. lacunosa & 12.6 & 84.0 & - & - & 3.4 & 1.86 \\
H. spec. X-4 & 14.3 & 7.8 & - & 75.2 & 2.7 & 1.90 \\
H. macrophylla & 15.1 & 13.9 & - & 66.8 & 4.3 & 1.82 \\
H. shepherdii & 16.6 & 9.0 & - & 72.1 & 2.3 & 1.71 \\
H. bandaensis & 18.2 & 23.0 & - & 57.8 & 1.0 & 2.33 \\
H. latifolia & 19.4 & 18.2 & - & 57.3 & 5.1 & 1.86 \\
H. imperialis & 20.7 & 73.5 & 1.9 & 0.3 & 3.6 & 2.06 \\
H. angustifolia & 23.4 & 15.3 & - & 58.3 & 3.0 & 1.76 \\
\hline
\end{tabular}

* lcfa: esters with long-chain fatty acids.

the percentages of cis-cinnamic acid were constant for the species analysed. In addition, cis-cinnamic acid could not be detected in the methyl ester fraction after saponification-methylation of pure $\alpha$-amyrin cinnamate [3].
Therefore, it can be concluded that small quantities of ciscinnamic acid always accompany trans-cinnamic acid in Hoya latices.

3-Phenylpropionic acid (hydrocinnamic acid) was 
found, with the exception of $H$. lacunosa, in all Hoya species, usually in small amounts. In the latex of $H$. species X-4 and $H$. shepherdii this acid is, together with cinnamic acid, a major acid of the triterpene ester fraction (Table 3 ). Benzoic acid was isolated from four latices. (Table 3). Isovaleric acid is the main acid of $H$. bella latex. It was also isolated in minor amounts from three other species (Table 2).

Long-chain fatty acids are present as minor components in almost all latices (Table 2). The most abundant fatty acids in Hoya latices are palmitic, oleic, linoleic and linolenic acids (Table 4). Oleic acid predominated in ten species; linoleic acid was the main fatty acid of seven latices. The other fatty acids found had from 14 to 21 carbon atoms and were mostly present in minor amounts. Myristic acid, however, was a main fatty acid in $H$. lacunosa latex, as was linolenic acid in $H$. bella and $H$. multiflora. Long-chain fatty acids with more than 21 carbon atoms were not observed in the latices.

Under greenhouse conditions, the aliphatic and aromatic acid composition of $\mathrm{Hoy}$ a latices was not affected by environmental factors such as light and temperature, or by plant age. Furthermore, seedlings of $H$. lacunosa and cuttings of $H$. bella obtained from different botanical gardens all showed the acidic pattern specific for those species. This suggests a very constant composition of the acids present in the latices of the Hoya species.

\section{Systematic implications}

Schumann [26] divided the genus Hoya into four sections on the basis of floral morphological differences. $H$. multiflora belongs to his section Cyrtoceras (Benn.) Hook. fil. and the other species to his section Euhoya Miq.

On the basis of the esterified acids in the latex particles of twenty Hoya species we can discern the following groups: (1) Acetate-rich particles, Table 2 shows predominance of acetates in the latex triterpene ester fraction

Table 3. Grouping of Hoya species with a high content of aromatic acids in the triterpene ester fraction (mol \%)

Phenyl

Species Cinnamate propionate Benzoate

\begin{tabular}{lccc}
\hline Cinnamate-rich particles & & & \\
H. fraterna & 88.6 & 0.4 & - \\
H. crassipes & 85.9 & 0.2 & - \\
H. cinnamomifolia & 82.6 & 0.3 & - \\
H. diversifolia & 81.7 & 0.1 & - \\
H. pseudolanceolata & 78.0 & 0.6 & - \\
H. obovata & 78.0 & 0.5 & - \\
H. spec. X-20 & 77.3 & 1.0 & - \\
H. australis & 70.7 & 0.9 & 2.0 \\
H. coronaria & 69.8 & 0.2 & - \\
H. ovalifolia & 69.3 & 1.0 & 0.6 \\
H. angustifolia & 57.8 & 0.5 & - \\
H. bandaensis & 56.1 & 1.7 & - \\
Cinnamate/phenylpropionate-rich particles & \\
H. spec. X-4 & 39.8 & 35.3 & - \\
H. shepherdii & 38.0 & 34.1 & - \\
Cinnamate/benzoate-rich particles & & \\
H. latifolia & 45.6 & 0.7 & 11.0 \\
H. macrophylla & 47.3 & 0.9 & 18.6 \\
\hline
\end{tabular}

of three Hoya species. Most of the esterified acids in this group have an acetyl-CoA origin; (2) Isovalerate-rich particles, Table 2 shows that large amounts of isovalerate occur in $H$. bella. In this species the pathway leading from leucine to isovalerate has apparently become of considerably quantitative importance. In $\boldsymbol{H}$. bella isovalerate replaces acetate as the main acidic triterpene ester constituent; and (3) Aromatic acid-rich particles. The occurrence of triterpene esters esterified with aromatic acids has been known for almost eight decades [8]. The present paper shows that three aromatic acids occur esterified in the latex particles of several Hoya species: benzoic acid, cinnamic acid and phenylpropionic acid (Table 3). The origin of these acids is the shikimate pathway; benzoic acid can also be synthesized by $\beta$-decarboxylation of cinnamate or phenylpropionate.

Within the third group, three subgroups can be distinguished (Table 3 ). In these subgroups $58-89 \%$ of the nonrubber particle lipid molecules are aromatic esters. Since the compositions of the latex particles of both species in group $3 \mathrm{~b}$ are very similar and the plants are also difficult to distinguish morphologically, it is probabule thât species $\mathrm{X} 4$ is actually $H$. shepherdii.

The latex particle composition is rather complicated. The triterpenols (1-5) present in the particles belong to several representatives of the tetracyclic and pentacyclic triterpenoids [20-23]. Three aromatic acids, two shortchain aliphatic acids and about 16 long-chain fatty acids are esterified with a smaller or larger fraction of these triterpenols.

In previous papers on Hoya species we have reported studies on constituents other than esterified acids of latices [20-23, 27, 28]. They support the grouping of Hoya species indicated in the present paper, as the following data show. Nearly all investigated Hoya species have a mixture of $\alpha$-amyrin and lupeol, $\beta$-amyrin and 24-methylenecycloartanol as the main latex triterpenols [20-23]. $H$. bella differs from these species with isobauerenol as the main latex triterpenol [20]. $\beta$-Amyrin predominates in the latex of $H$. australis, $H$. coronaria, $H$. ovalifolia and $H$. bandaensis [23]. These four species are also characterized by a relatively low percentage of cinnamate in the cinnamate-rich group (Table 3 ) and the presence of the flavonoid apigenin $O$-glycoside in the leaves $[23,28]$. Methyl esters of seco-triterpene acids were found in the leaf wax of $H$. australis, $H$. crassipes, and $H$. lacunosa [27]. Seco-nor-triterpenols were found to accumulate only in the waxes of $H$. australis and $H$. crassipes, both belonging to the cinnamate-rich group (Table 3 ).

The differences in the patterns of the triterpene esters are not in accord with the classification given by Schumann [26]. A modern systematic revision of the genus Hoya, however, is still needed. In our view the specific aromatic and fatty acid patterns in Hoya laticcs are useful taxonomic characters and should be taken in consideration in future taxonomic work. It should be borne in mind, however, that there are species or subspecies without any latex particles (e.g. $H$. carnosa and $H$. motoskei), in which these characters are absent.

\section{EXPERIMENTAL}

Hoya plants were cultivated in the greenhouse on a Hoagland nutrient solution or on soil. The plants used were cultivated from cuttings of specimens obtained from a number of botanical gardens [23]. The names were verified as far as possible. Voucher 


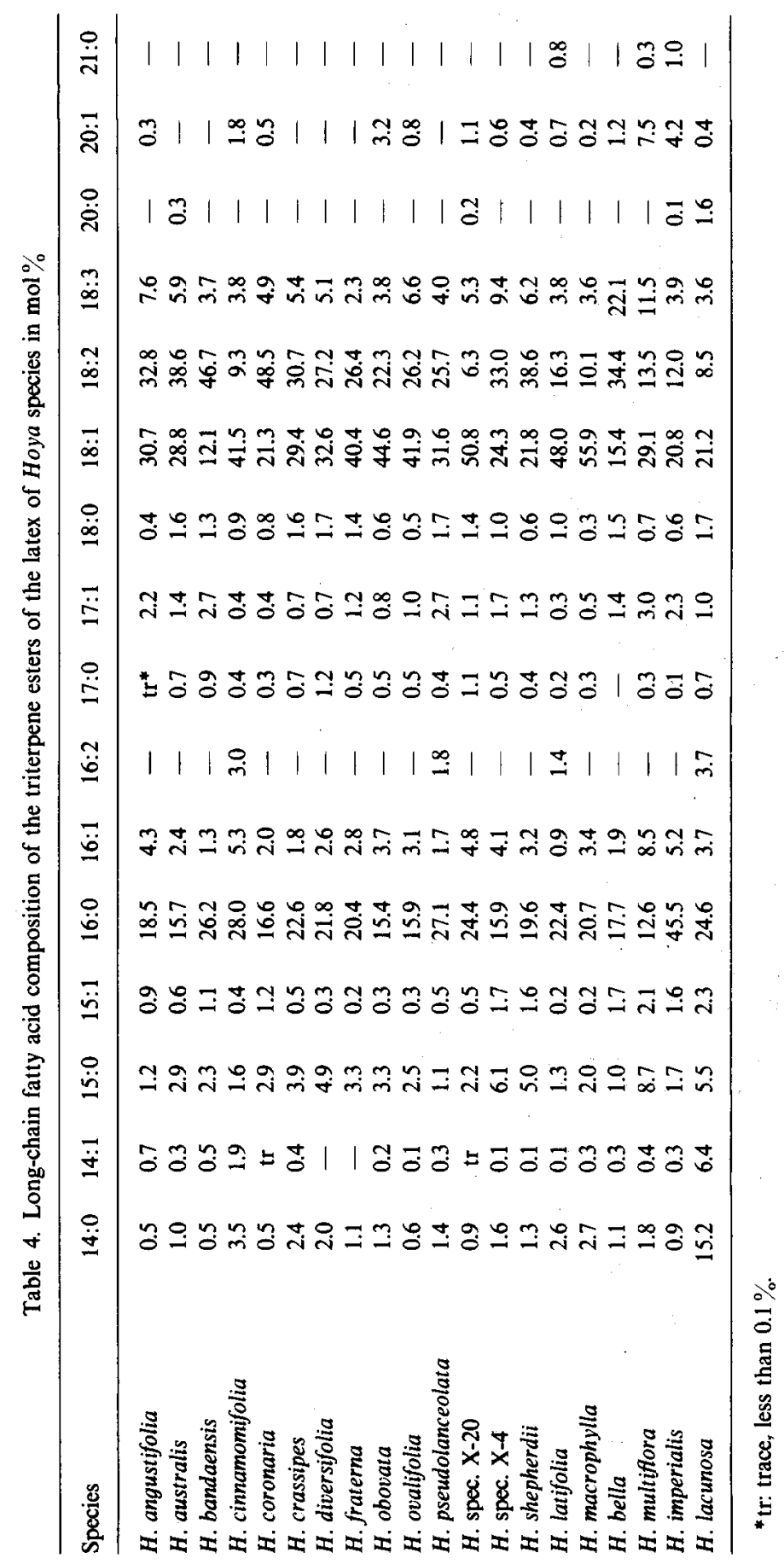


<smiles>CC1(C)CCC2(C)CCC3(C)C(=CCC4C5CCC(O)C(C)(C)C5CCC43C)C2C1</smiles>

$1 \beta$-amyrin<smiles>CC1CCC2(C)CCC3(C)C(=CCC4C5CCC(O)C(C)(C)C5CCC43C)C2C1C</smiles>

2 a - amyrin<smiles>CC1CCC2(C)CCC3(C)C4=C(CCC3C2C1C)C1CCC(O)C(C)(C)C1CC4</smiles>

3 isobauerenol<smiles>C=C(C)C1CCC2(C)CCC3(C)C(CCC4C5(C)CCC(O)C(C)(C)C5CCC43C)C12</smiles>

lupeol<smiles>C=C(CCC(C)C1CCC2(C)C3CCC4C(C)(C)C(O)CCC45CC35CCC12C)C(C)C</smiles>

524 - methylenecycloartanol specimens of all plants used were deposited in the herbarium of the Institute for Systematic Botany of the University of Utrecht, under the numbers indicated in Table 1.

Extraction and isolation of latex lipids. Latex $(0.5 \mathrm{ml})$ was tapped from leaf mid-veins or stalks. Extraction of the triterpenoids was carried out as described before [3]. The extracts were evapd to dryness under $\mathrm{N}_{2}$ and red. pres. and low temp. (35). The residues were chromatographed on a silica gel column $(5 \mathrm{~g})$. Elution with $2 \% \mathrm{Et}_{2} \mathrm{O}$-petrol gave the triterpene esters, $25 \%$ $\mathrm{Et}_{2} \mathrm{O}$-petrol the free triterpenols. Saponification-methylation of the triterpene ester fraction was done as reported before [3]. Polar lipids were extracted according to the method of Bligh and Dyer [29]. The quantity of rubber present was based on the amount of polyisoprene converted into the bromo-derivative according to Willits et al. [30].

$G C$ conditions. Free triterpenols and their acetate, isovalerate and benzoate esters were determined quantitatively by GC with FID on a $3 \%$ SE-30 column, temp. programmed $200^{\circ}$ to $300^{\circ}$ at $2^{\circ} / \mathrm{min}$, with $5 \alpha$-cholestane as IS. The determinations were performed with respect to relative weight responses, which were calculated according to Sternberg et al. [31] and determined on pure compounds. Aromatic acids were analysed as Me esters on a $10 \%$ Ap-L $\left(140^{\circ}\right)$ and a $25 \%$ DEGS $\left(180^{\circ}\right)$ column with Me 4 phenylbutyrate and Me stearate, respectively, as IS. Cinnamic acid was determined quantitatively subsequent to saponification-methylation [3]. Long-chain fatty acid Me esters were analysed on the Ap-L $\left(200^{\circ}\right)$ and the DEGS $\left(180^{\circ}\right)$ column with reference to $\mathrm{Me}$ heptadecanoate and $\mathrm{Me}$ stearate. Isovaleric acid was identified as free acid on a $15 \%$ PPGS column at $120^{\circ}$ [32]. GC was performed with $\mathrm{N}_{2}$ as carrier gas at $30 \mathrm{ml} / \mathrm{min}$. GC/MS $(70 \mathrm{eV})$ was carried out using a $3 \% \mathrm{SE}-30 \mathrm{column}$.

Acknowledgements-I thank Professor J. van Die and Professor R. Hegnauer for helpful suggestions and critical reading of the manuscript.

\section{REFERENCES}

1. Shukla, O. P. and Krishna Murti, C. R. (1971) J. Scient. Indian Res. 30, 640.

2. Altman, R. F. A. (1958) Chem. Abstr, 52, 506.

3. Warnaar, F. (1976) Analyt. Biochem. 71, 533.

4. Groeneveld, H. W. (1976) Acta Bot. Neerl. 25, 167.
5. Windaus, A. and Welsch, A. (1908) Arch. Pharm. 246, 504.

6. Ultée, A. J. (1934) Rec. Trav. Chim. Pays-Bas 53, 953.

7. Ultée, A. J. (1949) Pharm. Weekblad 84, 65.

8. Van Romburgh, P. (1904) Ber. Dtsch. Chem. Ges. 37, 3440, 4109.

9. Tschirch, A. and Schereschewski, E. (1905) Arch. Pharm. 243, 358.

10. Bosz, J. E. Q. and Cohen, N. H. (1912) Arch. Pharm. 250, 52.

11. Hillen, G. H. (1913) Arch. Pharm. 251, 94.

12. Heilbron, I. M., Kennedy, T. and Spring, F. S. (1938) J.Chem. Soc. 329.

13. Azpeitia, E., Bowers, A., Crabbé, P., Mancera, O., Matthews, J. S., Reynoso, J. and Salazar, J. (1961) Can. J.Chem. 39, 2321.

14. Hendricks, S. B. and Wildman, S. G. (1946) Arch. Biochem. $10,157$.

15. Murti, P. B. R. and Seshadri, T. R. (1943) Proc. Ind. Acad. Sci. $18 \mathrm{~A}, 145$.

16. Hesse, G., Eilbracht, H. and Reicheneder, F. (1941) Ann. Chem. 546, 233.

17. Warnaar, F. (1982) Z. Pfanzenphysiol. 105, 307.

18. Warnaar, F. (1977) Lipids 12, 707.

19. Warnaar, F. (1981) Phytochemistry 20, 89.

20. Baas, W. J. and Niemann, G. J. (1978) Z. Naturforsch. 34c, 5.

21. Baas, W. J. and Niemann, G. J. (1979) Planta Med. 35, 348.

22. Niemann, G. J., Baas, W. J., Besson, E. and Chopin, J. (1979) Z. Naturforsch. 34c, 1125.

23. Baas, W. J., Warnaar, F. and Niemann, G. J. (1981) Acta. Bot. Neerl. 30, 257.

24. Van Die, J. (1955) Ann. Bogorienses 2, 1.

25. Ultée, A. J. (1925) Pharm. Tijdschr. Ned.-Ind. 2, 515.

26. Schumann, K. (1895) in Die natürlichen Pfanzenfamilien (Engler, A. and Prantl, K., eds) Vol. IV, ii, pp. 289-291. Engelman, Leipzig.

27. Baas, W. J. (1982) Acta Bot. Neerl. 31, 449.

28. Niemann, G. J. (1981) Z. Naturforsch. 36c, 1084.

29. Bligh, E. C. and Dyer, W. J. (1959) Can. J. Biochem. 37, 911.

30. Willits, C. O., Swain, M. L. and Ogg, C. L. (1946) Ind. Eng. Chem. 18, 439.

31. Sternberg, J. C., Gallaway, W. S. and Jones, D. T. L. (1962) in Gas Chromatography (Brenner, N., Callen, J. E. and Weiss, M. D., eds) p. 265. Academic Press, New York.

32. Ziolecki, A. and Kwiatkowska, E. (1973) J. Chromatogr. 80, 250. 